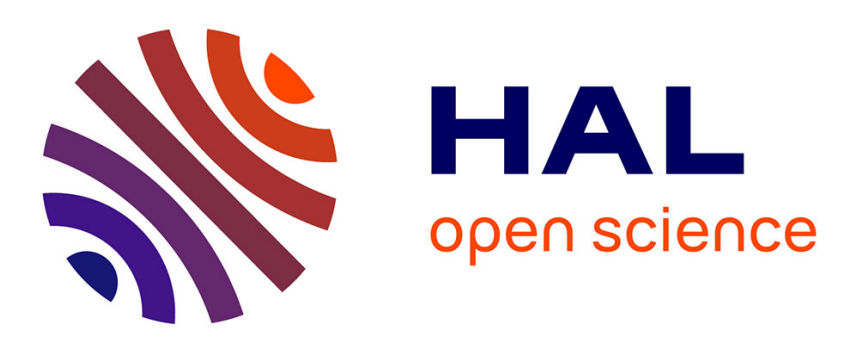

\title{
Influence of the growth and annealing atmosphere on the electrical conductivity of LTG crystals
}

Maroua Allani, N Batis, Thierry Laroche, A. Nehari, H Cabane, K. Lebbou, Jean J Boy

\section{- To cite this version:}

Maroua Allani, N Batis, Thierry Laroche, A. Nehari, H Cabane, et al.. Influence of the growth and annealing atmosphere on the electrical conductivity of LTG crystals. Optical Materials, 2017, 65, pp.99 -102. 10.1016/j.optmat.2016.09.072 . hal-02392622

\section{HAL Id: hal-02392622 \\ https://hal.science/hal-02392622}

Submitted on 4 Dec 2019

HAL is a multi-disciplinary open access archive for the deposit and dissemination of scientific research documents, whether they are published or not. The documents may come from teaching and research institutions in France or abroad, or from public or private research centers.
L'archive ouverte pluridisciplinaire HAL, est destinée au dépôt et à la diffusion de documents scientifiques de niveau recherche, publiés ou non, émanant des établissements d'enseignement et de recherche français ou étrangers, des laboratoires publics ou privés. 
archives-ouvertes

\section{Influence of the growth and annealing atmosphere on the electrical conductivity of LTG crystals}

Maroua Allani, N Batis, Thierry Laroche, A Nehari, H Cabane, K Lebbou, Jean Boy

\section{To cite this version:}

Maroua Allani, N Batis, Thierry Laroche, A Nehari, H Cabane, et al.. Influence of the growth and annealing atmosphere on the electrical conductivity of LTG crystals. Optical Materials, 2017, 65, pp.99 -102. hal-02392622

\section{HAL Id: hal-02392622 \\ https://hal.archives-ouvertes.fr/hal-02392622}

Submitted on 4 Dec 2019

HAL is a multi-disciplinary open access archive for the deposit and dissemination of scientific research documents, whether they are published or not. The documents may come from teaching and research institutions in France or abroad, or from public or private research centers.
L'archive ouverte pluridisciplinaire HAL, est destinée au dépôt et à la diffusion de documents scientifiques de niveau recherche, publiés ou non, émanant des établissements d'enseignement et de recherche français ou étrangers, des laboratoires publics ou privés. 


\title{
Influence of the growth and annealing atmosphere on the electrical conductivity of LTG crystals
}

\author{
M. Alani a, b, N. Batis b, T. Laroche c, A. Nehari ct, H. Cabane e, K. Lebbou d, *, J.J. Boy a \\ - FEMTO-ST Inslitute. UFC, CNRS. ENSMM. IJTBM. 25000 Besançon. France \\ bJNSAT, BP 676, 1080 Tunis Cedex, Tunisia \\ $c$ Freqlnlsys, TEMIS /nnovalion, 25000 Besançon. France \\ dInstitut Lumière Matière, UMR5306 UniversitéLyon 1-CNRS, Université de Lyon, Lyon 69622, Villeurbanne Cedex. France \\ - Cristal /nnov - Université Lyanl. 73800. Sainte-Hélène du Lac, France
}

\section{A R T I C L E I N F O}

\section{Article history:}

Received 19 May 2016

Received in revised form

28 September 2016

Accepted 28 September 2016

Available online $\mathrm{xxx}$

\section{Keywords:}

Langasite family

Defects

Electrical conductivity

Czochralski method

\begin{abstract}
A B S T R A C T
We present the electrical conductivity measurements of La $\mathrm{Ga}_{3} \mathrm{GSTaos}_{14}$ (LGT) crystals grown by Czochralski (Cz) technique in $\mathrm{r}$ crucibles and $\mathrm{N} 2$ atmosphere containing few percent of $0_{2}$. In addition, we have studied the effect of thermal annealing on the stability and the thermal conductivity. The electrical conductivity depends on the stoichiometry, the inhomogeneous impurities levels, the growth atmosphere and the post-growth annealing conditions. Furthermore, we recorded the UV-Vis transmission spectra of the LGT samples and we note that the less resistive LGT samples have an edge of the intrinsic absorption at the highest wavelengths.
\end{abstract}

\section{Introduction}

Owing to its high acoustic quality, its high piezoelectric coefficients and thermal stability, $\mathrm{La}_{3} \mathrm{Ga}_{55} \mathrm{Ta}_{0 .} \mathrm{S}_{14}$ (LGT) Langatate is a promising piezoelectric crystal for acoustic devices developed in the time and frequency domain and particularly for ultra-stable resonators (Bulk Acoustic Waves resonators) and high temperature wireless sensors. However, these applications require homogenous material with reproducible and performed properties.

In fact. during the growth by Czochralski process and postgrowth heat treatment defects are created in LGT crystal, which limits its potential use. Point defects, arising of the growth and post-growth conditions, can react as ionic and electronic charge carriers and generate conductive tosses particularly at high temperatures.

The presence of point defects significantly affects the physical and chemical properties. They can be revealed by chemical. optical and/or electrical analytical methods. In this paper, we present the characterization of the point defects and the electrical resistivity measurement of LGT crystals.

- Corresponding author.

E-mail address: kheirreddine.lebbou@univ-lyonl.fr (K. Lebbou).

\section{Experimental}

\subsection{The samples}

As presented previously [1.2], we have selected different LGT ingots grown under different conditions. For comparison, we selected LGS sample as standard. Details of the growth conditions, thermal annealing treatment and color are indicated in Table 1 which concerns 3 different sources: Cl (France), CK (USA) and FO (Russia).

\subsection{Chemical analysis of LGT crystals}

2.2.1. Electron Probe Micro-Analysis EPMA: major contents analysis

We have analyzed LGT samples by Electron Probe MicroAnalysis (EPMA) and we determined their atomic compositions. This microanalysis is performed on small polished samples (a few hundred square microns) having a thickness of about fifty microns. They are then bonded on resin or metal support. Each measurement corresponds to the average of a few tens of scans.

\subsubsection{Femtosecond laser ablation !CP-MS (analysis of traces and} ultra-traces of impurities)

Ail measurements were carried out on a DRC2 quadrupole ICPMS (Perkin Elmer) instrument coupled to an Alfamet 
Table 1

Growth and post-growth treatment (annealing) conditions of LGT samples and LGS sample.

\begin{tabular}{|c|c|c|c|c|}
\hline $\begin{array}{l}\text { Sample } \\
\text { reference }\end{array}$ & $\begin{array}{l}\text { Growth } \\
\text { axis }\end{array}$ & $\begin{array}{l}\text { Growth } \\
\text { atmosphere }\end{array}$ & Annealing conditions & Color \\
\hline $\mathrm{Cl} 3$ & $\mathrm{x}$ & $\mathrm{N}_{2}$ & Air, $1320^{\circ} \mathrm{C}, 24 \mathrm{~h}$ & $\begin{array}{l}\text { Heterogeneous } \\
\text { light orange }\end{array}$ \\
\hline ClGba & $x$ & $\mathrm{~N}_{2}$ & Before annealing & colorless \\
\hline Cl6aa & $\mathrm{x}$ & $\mathrm{N}_{2}$ & $\begin{array}{l}\mathrm{N}_{2}, 1400^{\circ} \mathrm{C}, 24 \mathrm{~h} \\
\text { (presence of few } \mathrm{O}_{2)}\end{array}$ & $\begin{array}{l}\text { Heterogeneous } \\
\text { light orange }\end{array}$ \\
\hline Fo & $\mathrm{x}$ & $\mathrm{Ar}+1 \% \mathrm{O}_{2}$ & Air, $1250^{\circ} \mathrm{C}$, several days & Bright orange \\
\hline CK & $\mathrm{Z}$ & & Not annealed & colorless \\
\hline LGS & $\mathrm{x}$ & $\mathrm{Ar}+1 \% \mathrm{O}_{2}$ & Air, $1250^{\circ} \mathrm{C}$, several days & Bright orange \\
\hline
\end{tabular}

ba: before annealing and aa:after annealing.

femtosecond laser ablation system (Nexeya SA, Canejan, France). This laser machine is fitted with a diode-pumped Yb:KGW crystal laser source (HP1, Amplitudes Systèmes, Pessac, France) delivering $360-\mathrm{fs}$ pulses at $1030 \mathrm{~nm}$. The laser beam is focused with a $25-\mathrm{mm}$ objective providing $15 \mu \mathrm{m}$ diameter spot size. Further details of a previous similar model of this laser ablation system are described elsewhere [3.4]. The final ablated zone is of $500 \mu \mathrm{m} \times 500 \mu \mathrm{m}$ in $50 \mathrm{~s}$. Each LGT was ablated 10 times under these conditions.

Measuring conditions were adjusted for maximum sensitivity, stability and plasma robustness using a transparent glass certified reference material (NIST 612) [5].

Trace metals concentrations were determined after calibration of the fs LA/ICPMS coupling using certified glass reference material (NIST 612 and NIST 610).

\subsection{UV-vis and IR spectroscopic analyses}

The presence of defects significantly affects the optical properties, which can be revealed by optical transmission spectra.

The transmission spectra of LGT samples with plane and parallel polished surfaces (thickness $4-5 \mathrm{~mm}$ ) were recorded in the wavelength range from 200 to $800 \mathrm{~nm}$ on a Lambda $900 \mathrm{UV}-\mathrm{VIS}$ spectrophotometer and in the range 7000 to $2000 \mathrm{~cm}^{-1}$ with a Magna 750 FT-IR spectrophotometer.

\subsection{Electrical resistivity measurements}

To calculate the electrical resistivity ( $\rho)$, Eq. (1), we measured the current intensity (I) crossing the sample at a voltage (U) of $50 \mathrm{~V}$ using a pico-ampere meter. The shape of LGT samples are disks of $14 \mathrm{~mm}$ diameter and $0.5 \mathrm{~mm}$ thick (e), with gold electrodes deposited $(S)$ on the two polished faces $(\phi=9 \mathrm{~mm})$.

$\rho(\Omega \cdot \mathrm{m})=\mathrm{U} / \mathrm{I} \cdot \mathrm{S} / \mathrm{e}$

\section{Results and discussion}

\subsection{Charge carriers}

LGT single crystals are generally grown by Czochralski method. The properties of this material and specificities of the growth process induce defects.

The LGT layered structure with four distinct cation sites allows incorporation of substituent and/or interstitial metal ions impurities. This result is confirmed by ICP-MS analyses (Table 2).

LGT is an incongruent material [6]. Stoichiometry derivations of the melt composition generate chemical inhomogeneity in the LGT crystal which are generally compensated by the formation of either cation or anion vacancies $\left(V_{\overline{0}}, V_{L_{a}}{ }^{\prime \prime \prime} \ldots\right.$... ). So, we analyzed the LGT samples by EPMA to determine their chemical compositions (Table 3).
Table 2

Impurities levels in LGT analyzed by Fs Laser Ablation ICP-MS coupling (in ppm weight).

\begin{tabular}{lllllllllllllll}
\hline Sample & $\mathrm{Na}$ & $\mathrm{Mg}$ & $\mathrm{Al}$ & $\mathrm{Ti}$ & $\mathrm{Cr}$ & $\mathrm{Fe}$ & $\mathrm{Ni}$ & $\mathrm{Cu}$ & $\mathrm{Zr}$ & $\mathrm{Sn}$ & $\mathrm{Ce}$ & $\mathrm{Pr}$ & $\mathrm{Gd}$ & $\mathrm{Ir}$ \\
\hline Cl6ba & 17 & 1 & 59 & 14 & 1 & 13 & $<0.1$ & 4 & 8 & $<0.1$ & 16 & 1 & 170 & $<0.1$ \\
Cl6aa & 59 & 3 & 165 & 10 & 1 & 14 & 10 & 1 & 8 & 19 & 16 & 1 & 171 & $<0.01$ \\
FO & 81 & 9 & 139 & 25 & 2 & 40 & 1 & 1 & 4 & 22 & 17 & 2 & 176 & 1 \\
\hline
\end{tabular}

Impurities levels in LGT analyzed by Fs Laser Ablation ICP-MS coupling (in Ppm weight).

Note: The high value of Gd content can be due to interferences with other atoms.

Table 3

Stoichiometry of LGT samples analysis by EPMA.

\begin{tabular}{lllll}
\hline Sample & $\begin{array}{l}\text { Cationic } \% \\
\text { x/(Ga + Ta }+ \text { La) }\end{array}$ & $\mathrm{x}=\mathrm{Ga}$ & $\mathrm{x}=\mathrm{La}$ & $\mathrm{x}=\mathrm{Ta}$ \\
\hline & Stoichiometry & 61.1 & 33.3 & 5.6 \\
CI6ba & average & 63.2 & 31.4 & 5.4 \\
Cl6aa & average & 63.4 & 31.4 & 5.2 \\
CI3 & average & 63.0 & 31.6 & 5.4 \\
CK & average & 63.1 & 31.6 & 5.3 \\
FO & average & 63.2 & 31.7 & 5.1 \\
\hline
\end{tabular}

These point defects can react as ionic $\left(\mathrm{V}_{\ddot{o}}-\mathrm{V}_{\mathrm{La}}{ }^{\prime \prime \prime}-\mathrm{Fe}_{1}^{\prime \prime \prime} \ldots\right)$ and electronic (é, h') charge carriers. Eq. (2) describes the bulk electrical conductivity.

$\sigma=\sum \mathrm{iC}_{\mathrm{i}} \mathrm{q}_{\mathrm{i}} \mu_{\mathrm{i}}$

where $C_{i}, q_{i}$ and $\mu_{i}$ are the concentration, the charge and the mobility of the $i$ charge carrier, respectively.

\subsubsection{Metal ions impurities}

From the results of fs LA-ICP-MS analysis, presented in Table 2, we note that LGT crystals are contaminated by impurities from raw materials oxides such as lanthanides ( $\mathrm{Ce}, \mathrm{Gd} . .$. coming from $\mathrm{La}_{2} \mathrm{O}_{3}$ and transition metals ( $\mathrm{Fe}, \mathrm{Ti}$...) from $\mathrm{Ta}_{2} \mathrm{O}_{5}$. These impurities occupy interstitial sites $\mathrm{Ti}_{1}^{\prime \prime \prime \prime}$ and/or substitute lattice atoms $\mathrm{Fe}_{\mathrm{Ta}}{ }^{\prime \prime}$.

Comparing the concentration of Fe and Ti in LGT FO and LGT Cl6aa samples, the intensity of the color increases with the concentrations of $\mathrm{Fe}$ and $\mathrm{Ti}$. We deduce that these impurities can contribute in LGT crystal color.

The variation of the impurities concentrations between the 2 samples CI6ba cut from un-annealed LGT ingot and CI6aa cut from the same LGT ingot after annealing, is due to inhomogeneous distribution of impurities.

After annealing, colorless LGT (CI6ba) became orange (Cl6aa). We deduce that annealing modifies the valence state of $\mathrm{Fe}$ and $\mathrm{Ti}$ impurities and then also the crystal color.

\subsubsection{Composition of LGT samples studied by EPMA}

In the $\mathrm{La}_{3} \mathrm{Ga}_{5.5} \mathrm{Ta}_{0.5} \mathrm{O}_{14}$ structure, $\mathrm{La}_{3}\left(\mathrm{Ga}_{0.5} \mathrm{Ta}_{0.5}\right)(1) \mathrm{Ga}_{3}(2) \mathrm{Ga}_{2}$ (3) $\mathrm{O}_{14}$, the $\mathrm{La}^{3+}$ cations occupy the dodecahedral sites and $\mathrm{Ga}^{3+}$ occupy three positions: octahedral Ga (1), which is partially

Table 4

LGT Electrical resistivity measurements.

\begin{tabular}{llllll}
\hline Sample & $\begin{array}{l}\text { Growth } \\
\text { atmosphere }\end{array}$ & $\begin{array}{l}\text { Annealing } \\
\text { atmosphere }\end{array}$ & $\mathrm{I}(\mathrm{nA})$ & $\rho(\mathrm{G} \Omega \mathrm{cm})$ & $\mathrm{Eg}(\mathrm{eV})$ \\
\hline ClGba & $\mathrm{N}_{2}$ & unannealed & 5.12 & 93.6 & 4,84 \\
CK & $\mathrm{N}_{2}$ & unannealed & 4.55 & 83.3 & 4.59 \\
LGS & $\mathrm{Ar}+\mathrm{O}_{2}$ & air & 5.33 & 64.2 & 3.54 \\
FO & $\mathrm{Ar}+\mathrm{O}_{2}$ & air & 5.39 & 45.3 & 3.26 \\
\hline
\end{tabular}




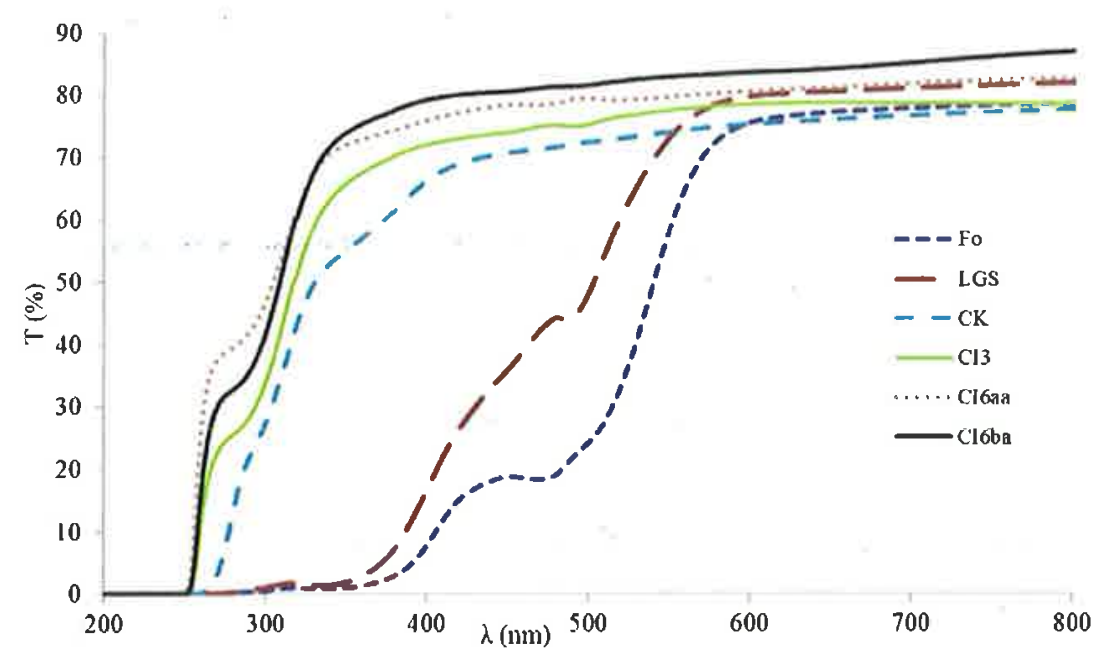

Fig. 1. UV-Vis transmission spectra of LGT samples.

occupied by $\mathrm{Ta}^{5+}$, tetrahedral Ga (2) and trigonal-pyramidal Ga (3). Comparing with the stoichiometric composition of LGT ( $\mathrm{La}_{3} \mathrm{Ga}_{5.5} \mathrm{Ta}_{0.5} \mathrm{O}_{14}$ ), the $\mathrm{Ga}$ content of the grown LGT crystals is higher while the Ta content is lower (Table 3 ). So, concerning the occupancy of the octahedral sites, we conclude that the Ga:Ta ratio is higher than 1, which indicates the presence of GaTa" defect in LGT crystal structure.

To conserve the electroneutrality, other point defects will be formed such as oxygen vacancies as presented in the quasichemical Eq. (3).

$$
\mathrm{Ga}_{2} \mathrm{O}_{3} \rightarrow 2 \mathrm{Ga}_{\mathrm{Ta}}{ }^{\prime}+2 \ddot{V}_{\mathrm{O}}+3 \mathrm{O}_{\mathrm{O}}
$$

The EPMA analysis of LGT crystals showed Lanthanum deficiency which leads us to suggest the existence of the hypothetical structure: $\mathrm{La}_{3} \mathrm{Ga}_{6} \mathrm{O}_{27 / 2}$. The LGT structure $\mathrm{La}_{3} \mathrm{Ga}_{5.5} \mathrm{Ta}_{0.5} \mathrm{O}_{27 / 2+1 / 2}$ can be written as $\operatorname{La}_{3}(1-1 / 27)\left(\mathrm{Ga}_{5.5} \mathrm{Ta}_{0.5}\right)_{(1-1 / 27)} \mathrm{O}_{27 / 2}$, knowing that $1 /(1+1 / 27) \approx 1-1 / 27$. We deduce that LGT is obtained by a partial substitution of Ga by $\mathrm{Ta}$ in the octahedral sites of the $\mathrm{La}_{3} \mathrm{Ga}_{6} \mathrm{O}_{27 / 2}$ structure. So,the substitution of one cation by another with higher valence Taça generates cationic vacancies as presented in the quasi-chemical Eq. (4).

$3 \mathrm{Ta}_{2} \mathrm{O}_{5} \leftrightarrow 6 \mathrm{Ta}_{\mathrm{Ga}} \cdot+4 \mathrm{~V}_{\mathrm{La}}{ }^{\prime \prime}+15 \mathrm{Oo}$

\subsection{Electrical resistivity}

Electrical resistivity measurements (Table 4), demonstrate that LGT crystal quality differs from sample to sample depending on the growth and thermal annealing conditions. LGT (CI) is twice more resistive than LGT (FO). Indeed, point defects, such as impurity, atoms vacancy, and atoms into interstitial position, add new energy levels in the band gap energy which induce higher bulk electrical conductivity.

In Ref. [7], the authors have calculated the band gap of defect-free LGT crystal at $5.279 \mathrm{eV}$. We determined the gap energy from the edge of the intrinsic absorption in UV-Vis transmission spectra (Fig. 1). Indeed, the less resistive LGT (FO) and LGS samples have an edge of the intrinsic absorption at higher wavelengths at $\lambda=350-380 \mathrm{~nm}$ compared with those of LGT (CI6ba) and CK at $\lambda=250-270 \mathrm{~nm}$.

\subsection{Influence of the growth and annealing atmosphere}

The presence of oxygen in the growth atmosphere increases the bulk electrical conductivity by the creation of charge carriers (Table 4) [8-10].

After air annealing, colorless LGT crystals become orange colored. It is due to the change of impurities valence state: for example, $\mathrm{Fe}^{2+}$ is oxidized into $\mathrm{Fe}^{3+}$.

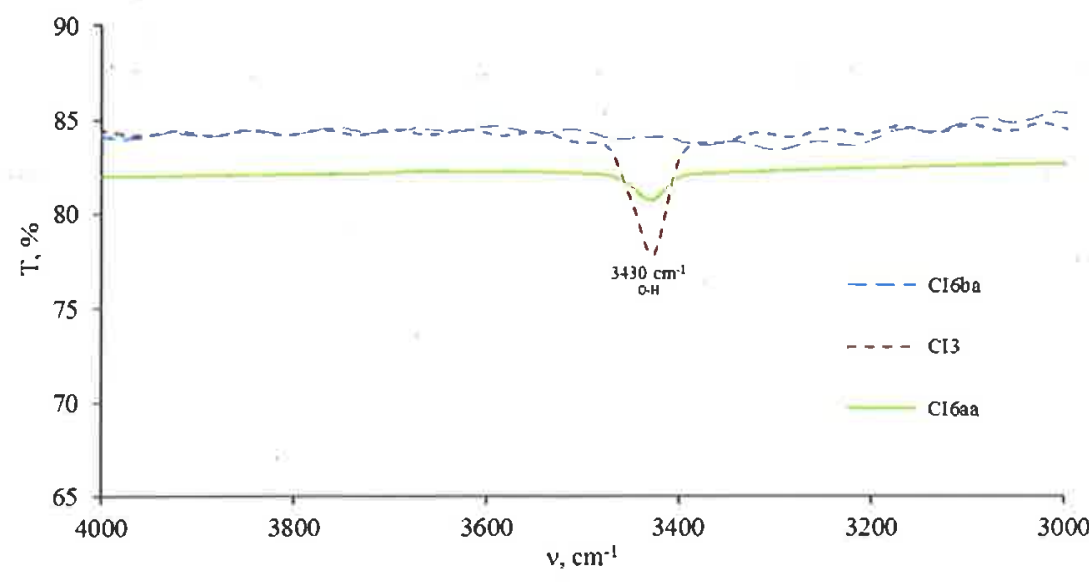

Fig. 2. IR transmission spectra of LGT samples. 
According to IR transmission spectra of LGT samples Fig. 2, annealing under Oxygen induces $\mathrm{OH}$ defect as described in the quasi-chemical Eq. (5).

$$
\begin{gathered}
1 / 2 \mathrm{O}_{2}+\ddot{V}_{\mathrm{O}}+2 \mathrm{e}^{\prime} \leftrightarrow \mathrm{O}_{\mathrm{O}} \\
\mathrm{O}_{\mathrm{O}}+\mathrm{H}^{-} \leftrightarrow \mathrm{OH}^{-}
\end{gathered}
$$

\section{Conclusion}

In this work, we have shown that the physical properties of the LGT crystals strongly depend on the growth conditions and thermal annealing. They can affect the stability of a given resonance frequency of Ultra Stable Resonators used in the frequency and time domain. We have observed that LGT samples grown and annealed in atmosphere containing Oxygen present higher electrical conductivity which is also affected by impurities levels.

\section{Acknowledgments}

This work was funded by the "Agence Nationale de la Recherche" (ANR-12-ASTR-0030-02) in the framework of a French research program ASTRID (supported by French MOD through DGA) with the project entitled "ECLATEMPS2012".

Dr B. Gauthier-Manuel (from FEMTO-ST) is gratefully acknowledged for his help and advice for IR and UV-Visible spectra. Our thanks also go to $\mathrm{Dr}$ C. Klemenz Rivenbark for very profitable talks about crystal growth of LGT and Dr C. Pecheyran for the ICP-MS analyses.

\section{References}

[1] J.J. Boy, M. Allani, N. Batis, O. Bel, 0. Cambon, J. Haines, P. Roumanille,
K. Lebbou, H, Cabane, A. El Hassouni, C. Pecheyran, New LGT crystal for ultrastable resonator's, in: Proc.. Of European Frequency and Time Forum, 2014, pp. $75-78$.

[2] M. Allani, X. Vacheret, A. Clairet, T: Baron, J. Boy, C. Reibel, O. Cambon, J.M. Lesage, O. Bel, H. Cabane, C. Pecheyran, How to qualify LGT crystal for acoustic devices?, in: Proc.. of the Joint Conference of the IEEE International Frequency Control Symposium \& European Frequency and Time Forum, 2015. pp. 100-105.

[3] F. Claverie, B. Fernández, C. Pécheyran, J. Alexis, O.F. Donard, Elemental fractionation effects in high repetition rate IR femtosecond laser ablation ICP-MS analysis of glasses, J. Anal. Atomic Spectrom. 24 (7) (2009) $897-902$.

[4] H. Tabouret, C. Bareille, F. Claverie, C. Pecheyran, P. Prouzet, O.F.X. Donard, Simultaneous use of strontium:calcium and barium:calcium ralios in otoliths as markers of habitat: application to the European eel (Anguilla anguilla) in the Adour basin, South West France, Mar, Environ. Res. 70 (1) (2010) 35-45.

[5] A. Barats, C. Pécheyran, D. Amouroux, S. Dubascoux, L. Chauvaud, O.F.X. Donard, Matrix-matched quantitative analysis of trace-elements in calcium carbonate shells by laser-ablation ICP-MS: application to the determination of daily scale profiles in scallop shell (Pecten maximus), Anal, Bioanal. Chem, 387 (3) (2007) 1131-1140.

[6] R, Fachberger, T. Holzheu, E. Riha, E. Born, P. Pongratz, H, Cerva, Langasite and Iangatate non uniform material proverties correlated to the performances of SAW devices, Proc. [EEE Inter Freq. Cont. Symp (2001) $235-239$.

[7] C.Y. Chung, R. Yaokawa, H. Mizuseki, S. Uda, Y. Kawazoe, First principles calculation of La3Ta0, 5Ga5. 5014 crystal with acceptor-like intrinsic pnint defects, J. Appl. Phys, 108 (11) (2010) 113505.

[8] O.A. Buzanov, N.S. Kozlova, E VZabelina, A.P. Kozlova, N.A Siminel, Optica transmission spectra and electrical properties of langasite and langatate crystals as dependent on growth conditions, Russ. Microelectron. 40 (8) (2011) 562-566.

[9] I.A. Kaurova, G.M. Kuzmicheva, A.B. Dubovskii, Physicochemica properties of La3Ga5. 5Ta0, 5014, [norg, Mater, 46 (10) (2010) $1131-1136$

[10] H. Kimura, S. Uda, O. Buzanov, X. Huang, 5, Koh, The effect of growth atmosphere and Ir contamination on electric properties of La3Ta0. 5Ga5. 5014 single crystal grown by the floating zone and Czochralski method, J. Electroceram. 20 (2) (2008) 73-80 